\title{
A new species of Ancistrus Kner, 1854 (Siluriformes: Loricariidae) from rio Madeira basin, Amazonas State, Brazil
}

\author{
Alessandro Gasparetto Bifi, Renildo Ribeiro de Oliveira \\ and Lúcia Rapp Py-Daniel
}

During the Mosaico do Apuí expedition in 2006, a new species of Ancistrus was found in the rio Sucunduri, a large tributary of the rio Madeira basin in south Amazonas State. The new species has a unique color pattern for the genus and is distinguished by the presence of alternate light and dark vertical bars on the trunk. Other Ancistrini genera have species with a similar color pattern, but the new species is clearly distinguished by a lack of plates on the snout and presence of fleshy tentacles on the snout as in all Ancistrus representatives. We also provide comments on the taxonomic status of the A. bolivianus, A. heterorhynchus and A. marcapatae.

Keywords: Ancistrini, Ancistrus bolivianus, Ancistrus heterorhynchus, Ancistrus marcapatae, Armored catfish.

Durante a expedição ao mosaico do Apuí em 2006, uma nova espécie de Ancistrus foi coletada no rio Sucunduri, um grande tributário da bacia do rio Madeira, na região sul do estado do Amazonas. A nova espécie possui um padrão de colorido único para o gênero e é diagnosticada pela presença de faixas verticais claras no tronco intercaladas com faixas escuras. Outros gêneros em Ancistrini possuem espécies com um padrão de colorido similar, porém a espécie nova é claramente distinta pela ausência de placas e presença de tentáculos no focinho, conforme todos os representantes de Ancistrus. Também fornecemos comentários sobre o status taxonômico de A. bolivianus, A. heterorhynchus e A. marcapatae.

Palavras-chave: Ancistrini, Ancistrus bolivianus, Ancistrus heterorhynchus, Ancistrus marcapatae, Cascudo.

\section{Introduction}

Loricariidae is the largest family of the Neotropical Siluriformes and is widespread from Costa Rica in the north to Argentina in the south (Weber, 2003). Ancistrus is one of richest loricariid genera, with 70 valid species (Fricke et al., 2019). The genus is easily distinguished from the other Loricariidae by having well-developed cheek spines, and the border of the snout naked, without plates, but ornamented with fleshy tentacles. Ancistrus is abundant in most museums or collections of fishes around the world, but often misidentified at species level due to the limited knowledge of its taxonomy. The type species of the genus, Ancistrus cirrhosus (Valenciennes, 1836), was described from Argentina, Buenos Aires and Misiones, but the holotype has never been found and may have not even been preserved (Fisch-Muller, 2003). Lack of a taxonomic revision of the genus has been the main cause of a never-ending list of taxonomic problems and difficulties with species recognition due to incomplete descriptions and lack of type material. Six species have been described from the rio Madeira basin: A. heterorhynchus (Regan, 1912) and A. marcapatae (Regan, 1904) from río Madre de Dios basin, Peru; A. bolivianus (Steindachner, 1915), A. megalostomus Pearson, 1924 and A. montanus (Regan, 1904) from río Beni basin, Bolivia; and A. verecundus Fisch-Muller, Cardoso, da Silva, Bertaco, 2005 from the igarapé Piracolina, upper rio Madeira, Brazil.

During an expedition to Mosaico do Apuí, a group of differently categorized but contiguous conservation units in the southern region of the Amazonas state, a new and peculiar species of Ancistrus was collected from the rio Sucunduri, rio Madeira basin. Almost all Ancistrus representatives possess light spots or vermiculations over a dark background. The new species is remarkable in having a unique color pattern among its congeners, and it is described here along with comments on the taxonomic status of A. bolivianus, A. heterorhynchus and A. marcapatae.

Coordenação de Biodiversidade, Coleção de Peixes, Instituto Nacional de Pesquisas da Amazônia, Av. André Araújo, 2936, Petrópolis, 69067-375 Manaus, AM, Brazil. (AGB) agbifi@gmail.com, Ohttps://orcid.org/0000-0001-6523-4359 (corresponding author); (RRO) deoliveirarr@gmail.com, Dhttps://orcid.org/0000-0001-6611-0833;(LRP) lucia.rapp@gmail.com, Đhttps://orcid.org/0000-0002-0954-7366 


\section{Material and Methods}

Measurements were taken using digital calipers to the nearest $0.1 \mathrm{~mm}$, and are presented as percents of standard length (SL) or head length (HL). Counts were made under a stereomicroscope. Measurements and counts followed Fisch-Muller et al. (2001) and Bifi et al. (2009). Body plate nomenclature was based on Schaefer (1997), with modifications of Oyakawa et al. (2005). Specimens were cleared and stained (c\&s) according to Taylor, Van Dyke (1985). Institutional acronyms: BMNH, Natural History Museum, London; CAS, California Academy of Sciences, San Francisco; INPA, Instituto Nacional de Pesquisas da Amazônia, Manaus; MCP, Museu de Ciências e Tecnologia, Pontifícia Universidade Católica do Rio Grande do Sul, Porto Alegre; MPEG, Museu Paraense Emilio Goeldi, Belém; MUSM, Museo de Historia Natural, Universidad Nacional Mayor de San Marcos, Lima; MZUSP, Museu de Zoologia da Universidade de São Paulo, São Paulo; NMW, Naturhistorisches Museum, Wien; ZMB, Berlin Zoological Museum, Berlin.

\section{Ancistrus miracollis, new species}

urn:1sid:zoobank.org:act:4D62A4E1-4BAF-4A2E-91123941327D3618

\section{Fig. 1-2, Tab. 1}

Holotype. INPA 57624, male, $66.7 \mathrm{~mm}$ SL; Brazil: Amazonas State: Apuí, comunidade Terra Preta, igarapé do Mureru, tributary of rio Sucunduri, rio Madeira basin, 745'45”S 5849'00”W, 29 Jun 2006, L. H. Rapp PyDaniel, C. E. Marinelli \& C. S. da Silva.

Paratypes. All from Brazil: Amazonas State: Apuí: rio Madeira basin: INPA 26144, 1, $59.0 \mathrm{~mm} \mathrm{SL}$, igarapé located just off the trilha do Inferno, tributary of rio

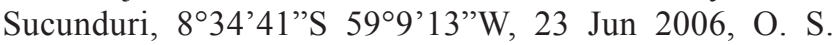
Pereira. INPA 26433, 27 (25 alc., 21.7-64.4 mm SL and 2 c\&s 48.9-54.0 mm SL); MCP 54133, 2, 45.0-48.7 mm SL; MPEG 38161, 2, 51.1-56.2 mm SL; MZUSP 124264, 2, 47.5-59.5 mm SL, same data of holotype.

Diagnosis. Ancistrus miracollis is diagnosed from its congeners by having thin light vertical bands on the trunk, sometimes incomplete (vs. plain, with black or white spots, or unpigmented body). Furthermore, the new species can be distinguished from other Ancistrus species described from the rio Madeira basin by pectoral-fin length surpassing the pelvic-fin origin ( $v s$. not reaching or just reaching the pelvic-fin origin in A. marcapatae, $A$. megalostomus and $A$. montanus); larger cleithral width $33.5-36.9 \%$ in SL (vs. $27.7-33.0 \%$ in A. montanus); smaller dentary width $45.3-54.4 \%$ in interorbital distance (vs. $64.6-86.6 \%$ in A. marcapatae and $64.9-91.4 \%$ in $A$. melagostomus); and by possession of an adipose-fin (vs. adipose-fin absent in $A$. verecundus).

Description. Morphometric data and counts in Tab. 1. Head and trunk moderately depressed. Dorsal profile of body convexly raising from tip of snout to dorsal-fin origin, then straight or slightly convex to adipose fin, and concave from that point to caudal fin. Ventral profile of body straight, slightly convex on caudal peduncle. Caudal peduncle compressed; slightly flattened ventrally.

Snout large and rounded in dorsal view, with large naked margin bordered by dermal platelets on lateral portion; extension of naked area on snout large, representing $2 / 3$ of snout length. Adult males with small- to middle size tentacles (sometimes branched) along lateral border of snout and longitudinally aligned along mesethmoid, bifurcating caudally to nares; tentacles small and less numerous in females, limited to one series on lateral border of snout. Evertible cheek plates supporting (17-33) hypertrophied odontodes (cheek spines). Head covered by dermal bones; dorsum covered by dermal plates, except at dorsal-fin base.

Eye mid-sized, 15.8-19.8\% of HL, dorsal orbit not raised; dorsolaterally positioned. Interorbital region slightly concave. Exposed portion of opercle roughly triangular; supra-opercular region with few platelets near compound pterotic.

Oral disk circular covered with small papillae; lower lip wide with papillae reducing in size toward its margin; maxillary barbel short, attached to lip by membrane and with reduced free tip. Premaxillary and dentary tooth rows short; teeth short, thin, numerous, bifid and curved inward. Cusps spatulated and asymmetrical, with mesial cusp larger and wider than lateral cusp. Only one small buccal papilla positioned between premaxillae.

Five series of lateral plates, three lateral series on the narrowest portion of caudal peduncle. Mid-dorsal and midventral series not surpassing adipose fin. Median series supporting lateral line. Short odontodes on fin rays and body plates. Ventral surface devoid of plates from snout tip to anal-fin insertion. Base of first anal-fin pterygiophore exposed, forming preanal platelet-like element, sometimes covered by skin but supporting small odontodes.

Dorsal-fin origin situated slightly anterior to vertical through pelvic-fin origin; dorsal fin usually reaching or surpassing preadipose plate when adpressed; dorsalfin spine flexible, shorter than head length. Adipose-fin spine short, slightly curved downward. Pectoral-fin spine inflexible and slightly curved inward, with hypertrophied odontodes and tentacles on its distal portion; pectoral-fin surpassing adpressed pelvic-fin origin. Pelvic fin flexible and curved inward, depressed pelvic-fin spine surpassing origin of anal fin. Anal fin short. Caudal-fin margin obliquely truncate with ventral unbranched ray longer than dorsal one. Fin-ray formula: dorsal II,7; pectoral I,6; pelvic i,5; anal i,3-4; caudal i,14,i. Total vertebrae: 27 (two specimens). 


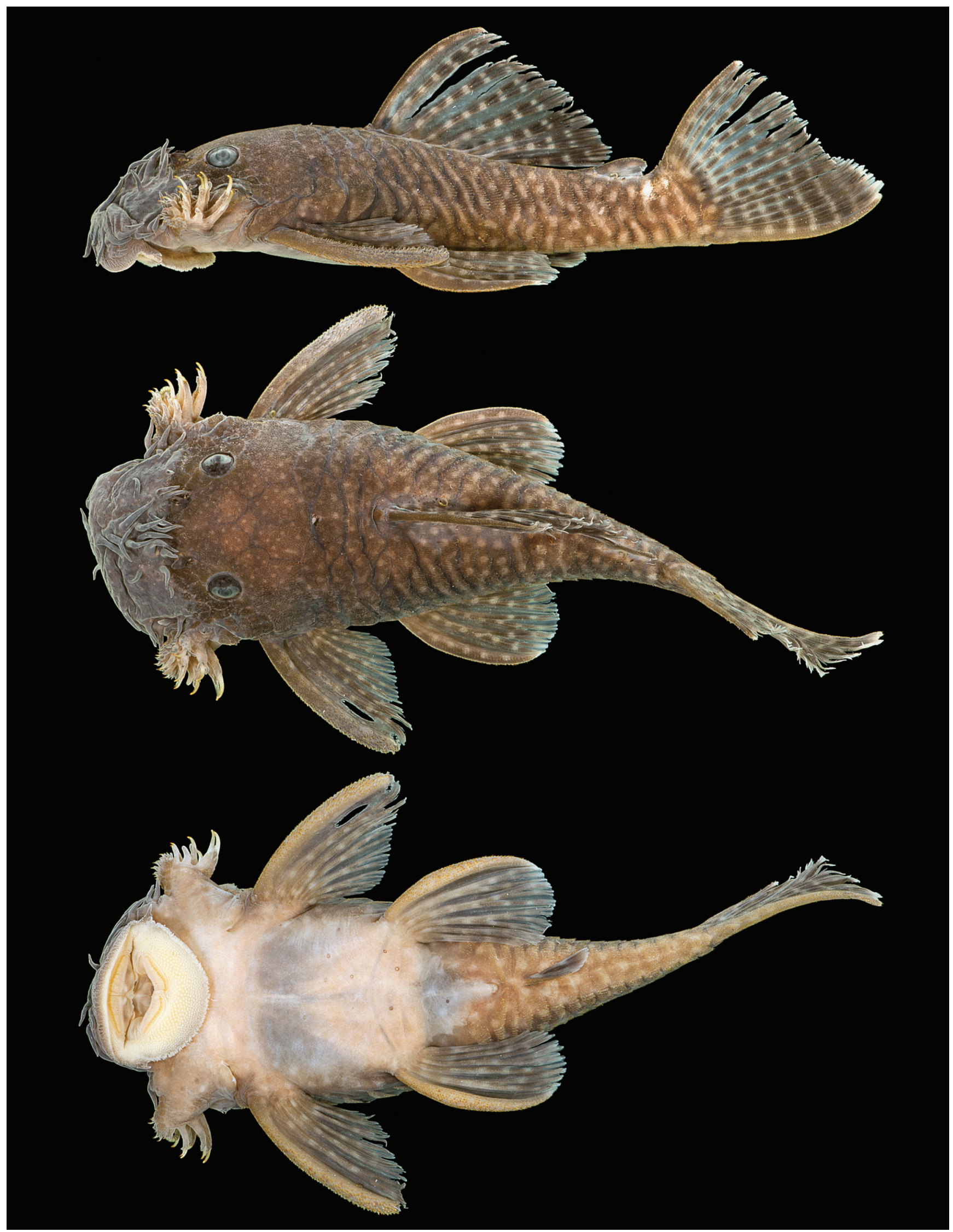

Fig. 1. Ancistrus miracollis, INPA 57624, holotype, $66.7 \mathrm{~mm}$ SL, male; Brazil, Apuí, rio Sucunduri drainage, lower rio Madeira basin. 
Tab. 1. Morphometric and meristic data of Ancistrus miracollis. $\mathrm{SD}=$ standard deviation, $\mathrm{N}=$ number (including holotype).

\begin{tabular}{|c|c|c|c|c|c|}
\hline Characters & Holotype & $\mathrm{N}$ & Range & Mean & $\mathrm{SD}$ \\
\hline \multicolumn{6}{|c|}{ Percent of standard length } \\
\hline Head length & 39.2 & 21 & $35.2-39.2$ & 36.7 & 1.0 \\
\hline Occipital depth & 20.6 & 21 & $16.8-20.6$ & 18.4 & 1.1 \\
\hline Dorsal-fin base length & 23.8 & 21 & $21.9-24.2$ & 23.5 & 0.6 \\
\hline Interdorsal length & 14.5 & 21 & $14.5-17.6$ & 16.0 & 0.8 \\
\hline Prepectoral length & 30.7 & 21 & $27.4-31.4$ & 29.3 & 0.9 \\
\hline Prepelvic length & 49.4 & 21 & $49.1-53.8$ & 51.2 & 1.2 \\
\hline Adipose-fin spine length & 8.9 & 21 & $8.0-11.1$ & 9.3 & 0.6 \\
\hline Anal-fin spine lenght & 10.0 & 20 & $8.0-10.6$ & 9.3 & 0.7 \\
\hline Thoracic length & 22.1 & 21 & $22.1-26.8$ & 25.2 & 1.3 \\
\hline Abdominal length & 22.0 & 20 & $19.1-22.4$ & 21.0 & 0.8 \\
\hline Upper caudal-fin spine length & 22.0 & 12 & $20.8-23.9$ & 22.4 & 0.9 \\
\hline Lower caudal-fin spine length & 30.2 & 18 & $29.3-36.3$ & 32.7 & 2.1 \\
\hline Caudal peduncle length & 26.9 & 20 & $26.9-29.4$ & 27.8 & 0.7 \\
\hline Caudal peduncle depth & 11.7 & 21 & $10.7-12.3$ & 11.6 & 0.4 \\
\hline Orbital diameter & 15.8 & 21 & $15.8-19.8$ & 17.7 & 1.1 \\
\hline Occipital-orbital distance & 42.8 & 21 & $37.8-43.3$ & 40.7 & 1.6 \\
\hline Dentary width & 19.3 & 21 & $17.3-19.7$ & 18.7 & 0.8 \\
\hline \multicolumn{6}{|c|}{ Count } \\
\hline Lateral median series & 23 & 21 & $22-23$ & 23.0 & 0.2 \\
\hline Dorsal-fin base & 7 & 21 & $6-7$ & 6.6 & 0.5 \\
\hline Between dorsal and adipose & 5 & 21 & $5-6$ & 5.5 & 0.5 \\
\hline Between adipose and caudal & 5 & 21 & $5-7$ & 5.9 & 0.5 \\
\hline Between anal and caudal & 11 & 21 & $11-12$ & 11.1 & 0.3 \\
\hline Premaxillary teeth & 57 & 21 & $50-65$ & 55.7 & 4.3 \\
\hline Dentary teeth & 61 & 21 & $52-69$ & 58.1 & 3.7 \\
\hline Cheek spines & 33 & 21 & $17-33$ & 21.8 & 4.1 \\
\hline
\end{tabular}

Color in alcohol. Body background color dark gray or brown. Dorsal part of head with rounded light spots, on predorsal and dorsum region in some specimens; light vertical bars on trunk, variably incomplete, usually more conspicuous on caudal peduncle region. Barred pattern showing some variation (Fig. 2). Ventral surface of head and abdomen yellowish to light brown, brown on ventral surface of caudal peduncle. All fins with alternating dark and light spots on rays, organized in transverse bands in some specimens. 


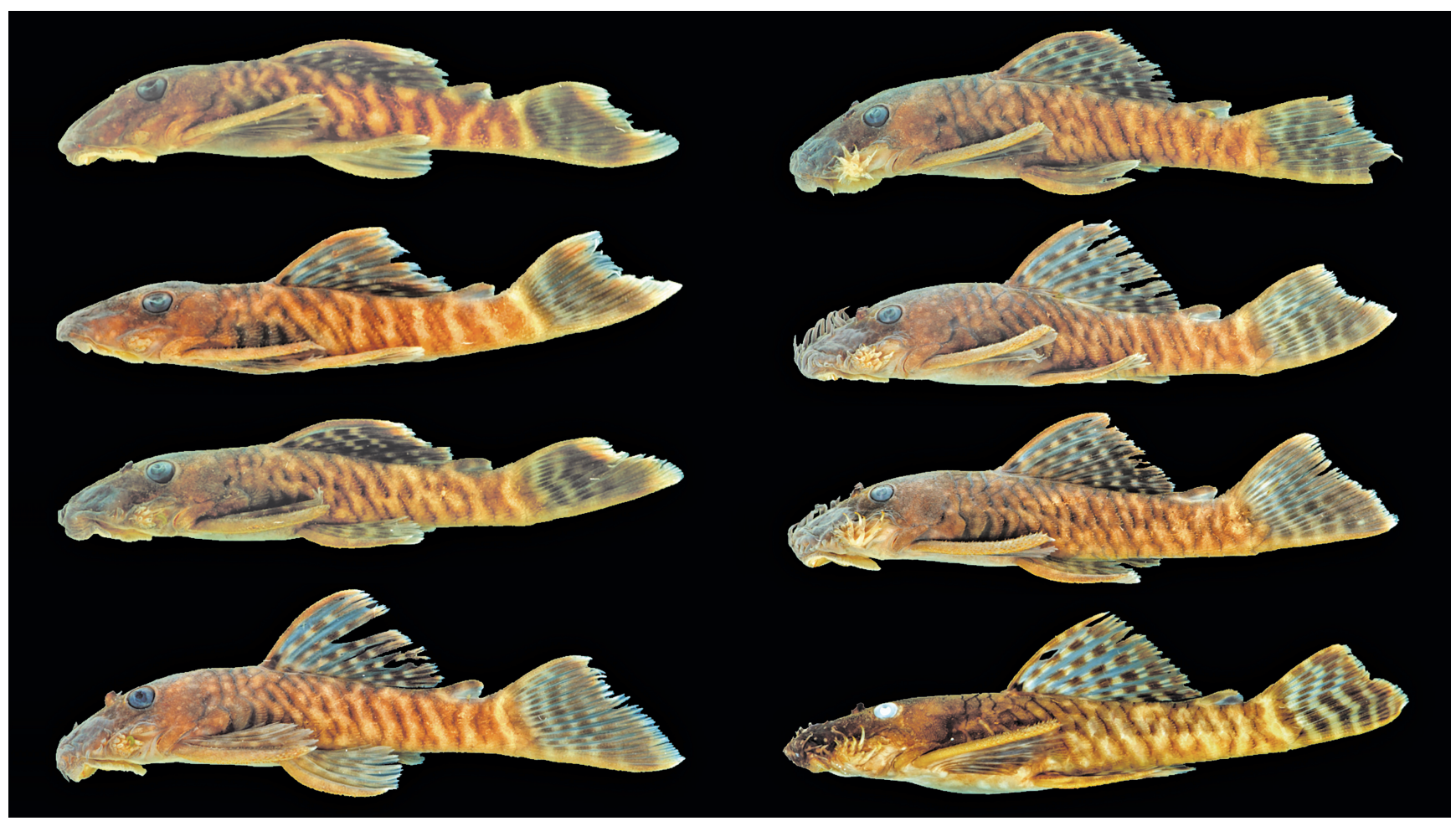

Fig. 2. Color pattern variation in Ancistrus miracollis. Standard length from top to bottom, left to right: $27.7 \mathrm{~mm}$ SL, $30.3 \mathrm{~mm}$ SL, 35.5 mm SL, $41.2 \mathrm{~mm}$ SL, 48.4 mm SL, $51.6 \mathrm{~mm}$ SL, 58.4 mm SL (all from INPA 26433), 60.1 mm SL (INPA 24144).

Sexual dimorphism. Ten males and 11 females measured; largest male and female with $66.7 \mathrm{~mm}$ and $67.4 \mathrm{~mm} \mathrm{SL}$, respectively. Mature males have small- to middle-sized tentacles in the dorsal region and border of snout. Females can have fewer and shorter tentacles than males limited to one series on lateral border of snout, usually two to four on each side of snout.
Geographical distribution. Ancistrus miracollis is only known from the Mosaico of Conservation Units of Apuí on southern Amazon State, near the border with Mato Grosso State, Brazil. The new species was found in small streams flowing to the rio Sucunduri, affluent of lower rio Madeira (Fig. 3).

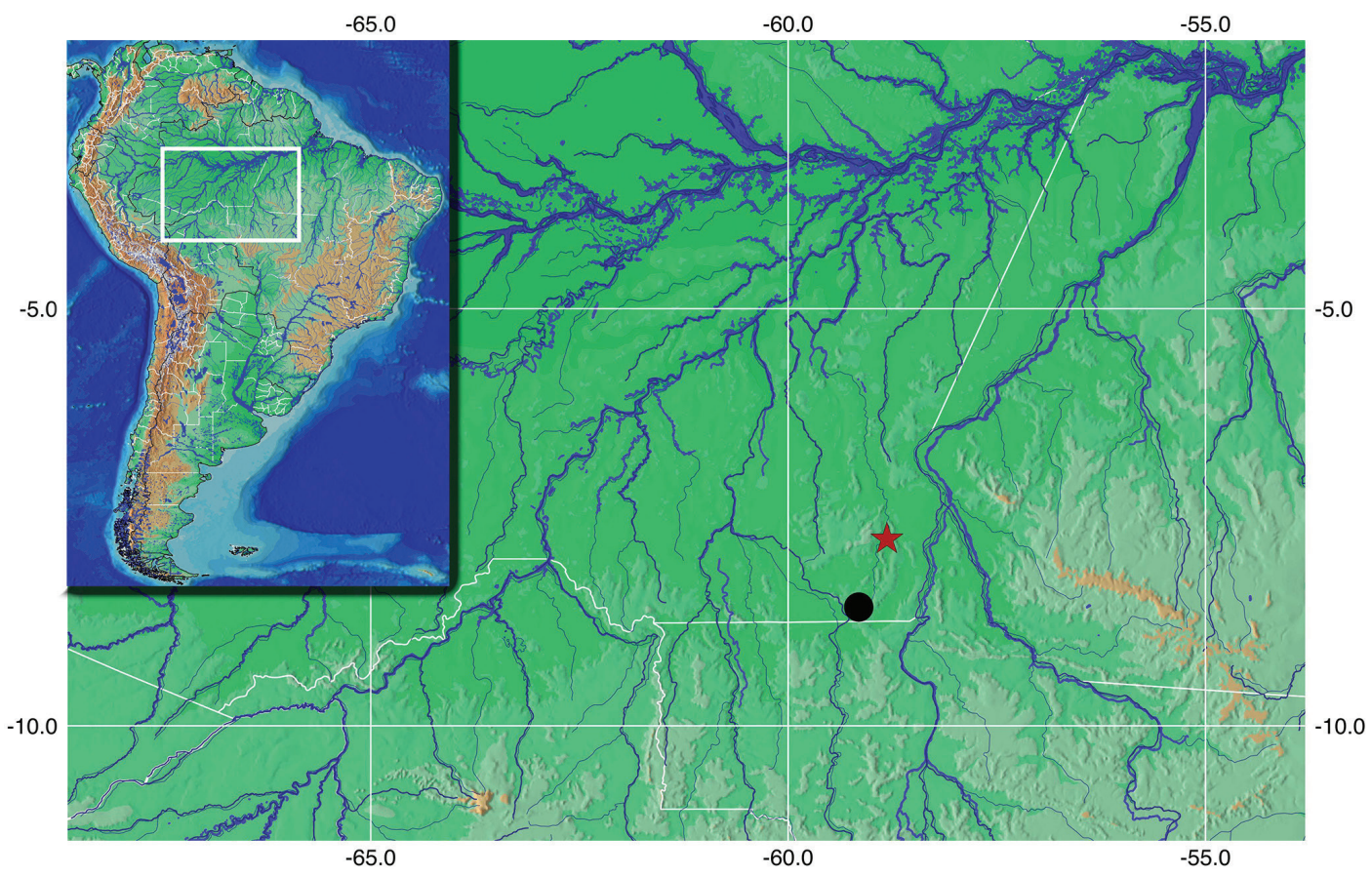

Fig. 3. Partial map of the Brazilian Amazon, showing the distribution of Ancistrus miracollis. Red star indicates type locality. 
Etymology. From the latim mirus = wonderful, surprising and collis = hill, mountain, in allusion to the beauty of the species with unique pattern color of Ancistrus and its sampling site in the highlands of the Parque Estadual do Sucunduri, more specifically in the Sucunduri Dome, an allusion to its elevation that can reach up to $350 \mathrm{~m}$, very peculiar for this area. An adjective.

Conservation status. The type locality of $\mathrm{A}$. miracollis (igarapé do Mureru) is not an easily accessible place and the sampling was made possible through governmental funds from the state of Amazonas (Secretaria de Desenvolvimento Sustentável do Amazonas - SDS). The Mosaic of Apuí comprises nine conservation units, seven considered of sustainable usage, and two State Parks under full protection. Thus, we suggest that $A$. miracollis be categorized as LC (Least Concern) under the International Union for Conservation of Nature (IUCN) categories and criteria (IUCN Standards and Petitions Subcommittee, 2017) of extinction risk.

Comments on taxonomic status of Ancistrus marcapate: Three species have been described from ríos Beni and Madre de Dios basins: A. bolivianus, A. heterorhynchus and $A$. marcapatae (Fig. 4). The examination of the type material revealed no differences between these three species, but that they share some uncommon features such as: teeth with elongated principal cusp sharpened and at least three times larger than lateral cusp; pectoral-fin not surpassing the pelvic-fin origin; and anterior adiposefin keel formed by four to six plates. Furthermore, these species have a slightly concave profile between adipose and caudal fins; dentary length (24.9-29.5\% in HL), and fins with dark spots forming transverse bands. These characters combinations distinguish them from the majority of Ancistrus species. Thus, based on these observations we recognize A. bolivianus and A. heterorhynchus as junior synonyms of $A$. marcapatae (Fig. 5).

\section{Ancistrus marcapatae (Regan, 1904)}

\section{Figs. 4-5}

Chaetostomus marcapatae Regan, 1904:246, pl.14 (Fig. 1) [original description; type locality: Marcapata Valley, río Inambari basin, Peru].

Xenocara heterorhynchus Regan, 1912:668, pl.76 (Fig. 2) [original description; type locality: Urohuasi, río Inambari basin, Peru].

Xenocara boliviana Steindachner, 1915:95, pl.9 (Figs. 5-6) [original description; type locality: río Songo, río Beni basin, Bolivia].

Chaetostoma marcapatae. - Isbrücker, 1980:62 [check list]. -Ortega, Vari, 1986:16 [check list]. -Fish-Muller, 2003:346 [check list]. -Ferraris, 2007:221 [check list].

Ancistrus bolivianus. - Isbrücker, 1980:66 [check list]. -FishMuller, 2003:374 [check list]. -Ferraris, 2007:219 [check list]. New Synonym.

Ancistrus heterorhynchus. - Isbrücker, 1980:69 [check list]. -Ortega, Vari, 1986:17 [check list]. -Fish-Muller, 2003:381 [check list]. -Ferraris, 2007:229 [check list]. New Synonym.

Ancistrus marcapatae. - Lujan et al., 2015b:673 [comments; new genus combination].

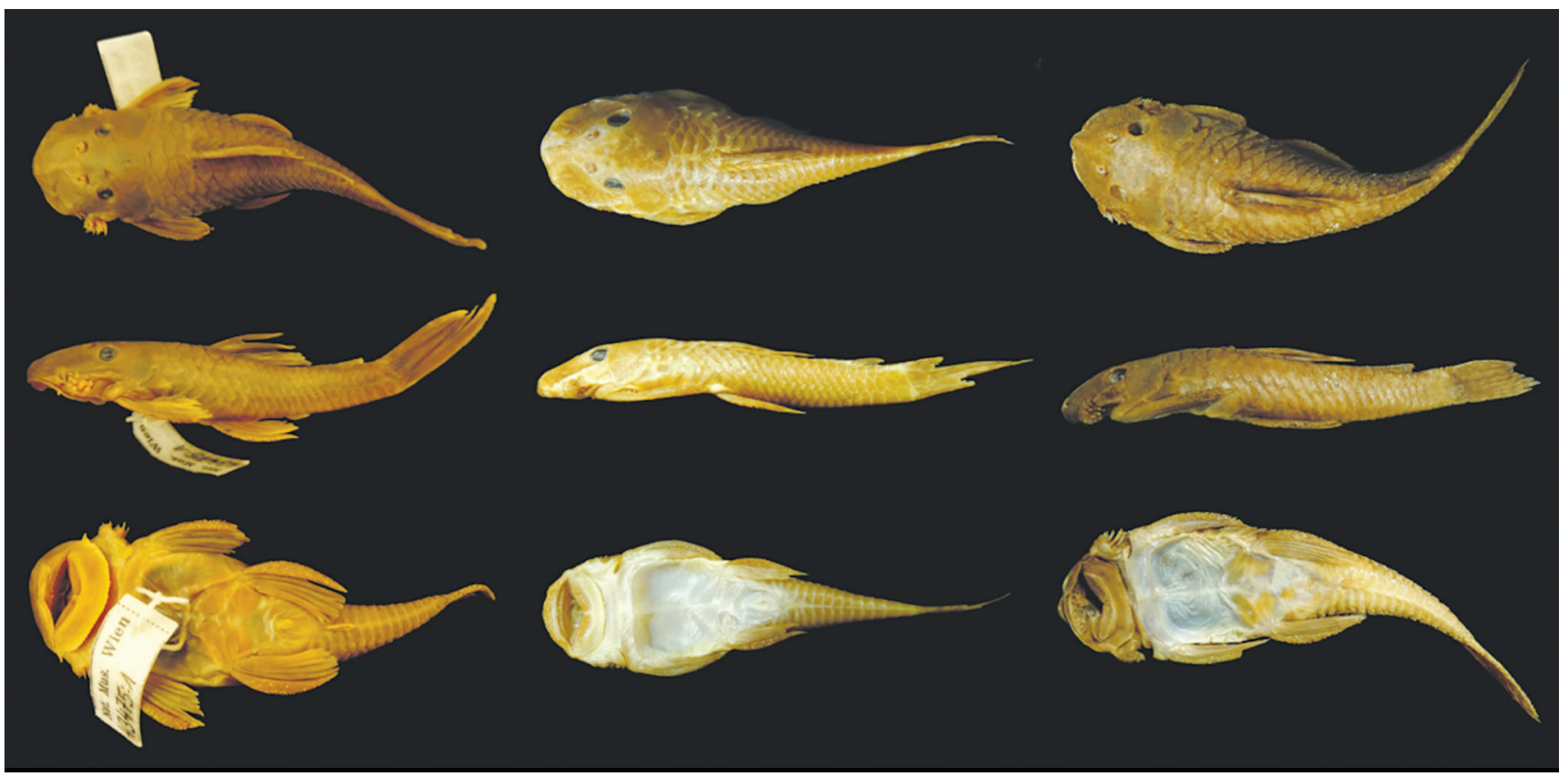

Fig. 4. Dorsal, lateral and ventral views (left to right) of Ancistrus bolivianus: NMW 43475, $65.6 \mathrm{~mm}$ SL, syntype; A. heterorhynchus: BMNH 1911.12.20.35-36, 63.2 mm SL, syntype; A. marcapatae: BMNH 1902.5.29.211, 79.1 mm SL, holotype. 


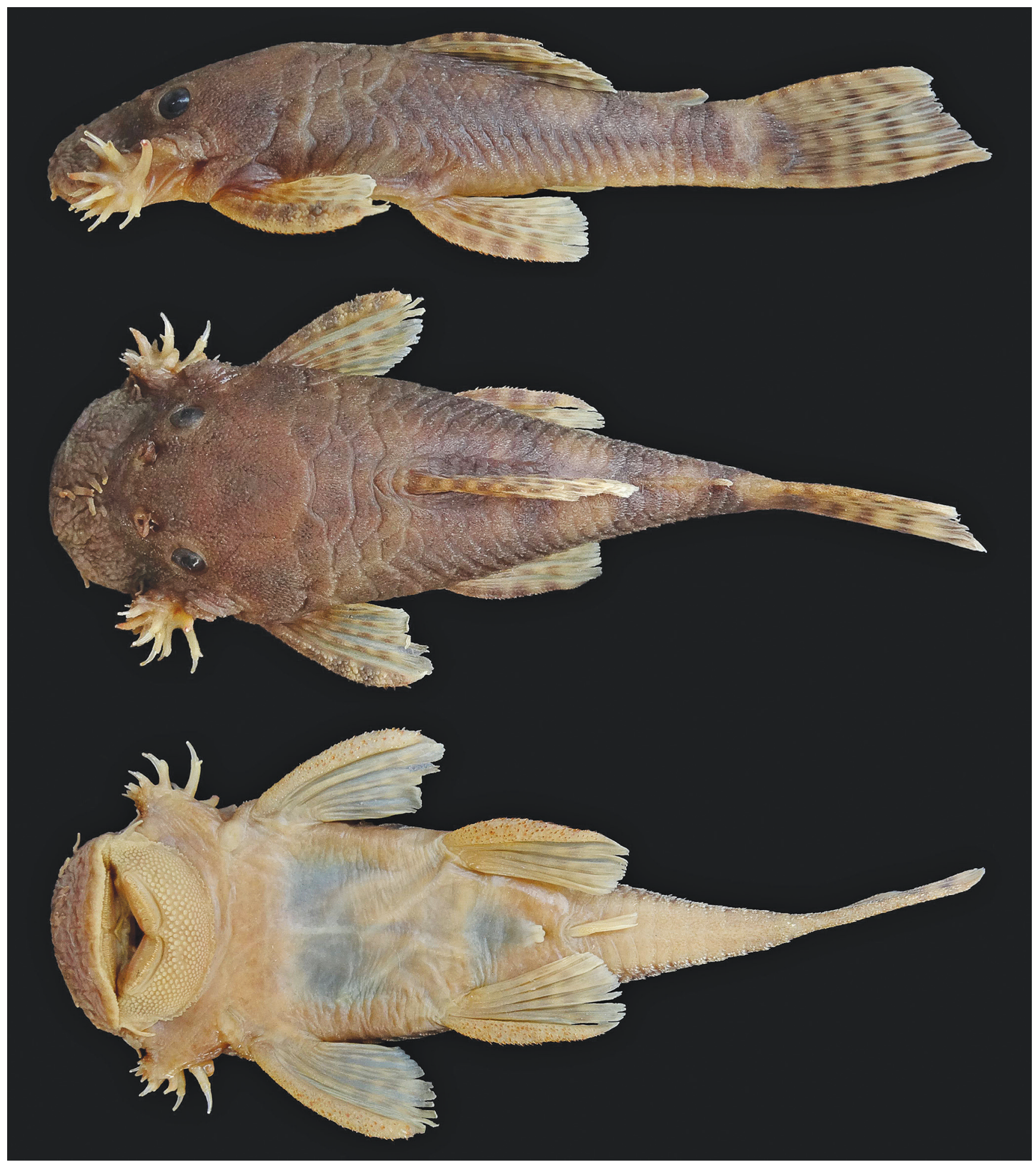

Fig. 5. Ancistrus marcapatae, MUSM 57853, 54,6 mm SL, male; Peru, Manu, rio Madre de Dios drainage, rio Adanrayo.

Examined material: Bolivia. Ancistrus bolivianus. NMW 43475, 2, 40.8-58.0 mm SL, syntypes of Xenocara boliviana Steindachner, 1915. Nord Yungas, río Madre de Dios basin, río Songo, 1914, Schnel; NMW 43476, 27, 31.2-65.6 mm SL, Nord Yungas, río Madre de Dios basin, río Songo, 1915, Fassl. Ancistrus heterorhynchus. BMNH 1911.12.20.35-36, 2, 45.7-63.2 mm SL, syntypes of Xenocara heterorhynchus
Regan, 1912, Madre de Dios basin, río Inambari basin. Peru. Ancistrus marcapatae. BMNH 1902.5.29.211, 79.1 mm SL, holotype of Chaetostomus marcapatae Regan, 1904, Marcapata Valley, río Inambari basin; MUSM 10087, 1, 88.5 mm SL, río Inambari basin; MUSM 57498, 1, 66.6 $\mathrm{mm}$ SL, río Inambari basin; MUSM 58097, 2, 57.9-59.9 mm SL, río Yunguyo, río Madre de Dios basin. 


\section{Discussion}

Although there are differences between Ancistrus based on morphological (Armbruster, 2004, 2008) and molecular analyses (Lujan et al., 2015a), there is some resemblance between Ancistrus and Lasiancistrus Regan, 1904 and Pseudolithoxus Isbrücker, Werner, 2001. Among these genera, only two species of Pseudolithoxus have a similar color pattern to A. miracollis: P. tigris (Armbruster, Provenzano, 2000) and P. kelsorum (Lujan, Birindelli, 2011), besides other genera like Dekeyseria Rapp PyDaniel, 1985, Hypancistrus Isbrücker, Nijssen, 1991, Peckoltia Miranda Ribeiro, 1912 and Panaqolus Isbrücker, Schraml, 2001. However, all can be distinguished from Ancistrus by having plates or odontodes on the snout and the lack of fleshy tentacles in adult male.

Seven valid species of Ancistrus are recorded from the rio Madeira basin (Fish-Muller, 2003; Ferraris, 2007): A. dolichopterus Kner, 1854; A. dubius Eigenmann, Eigenmann, 1889; A. hoplogenys (Günther, 1864); $A$. marcapatae; A. megalostomus; A. montanus and $A$. verecundus; and three additional species probably new to science: Ancistrus sp. "sideral"; Ancistrus sp.1 "baixinho" and Ancistrus sp.2 "sotério" (Zawadzki, Chamon, 2013). None of these species present the color pattern of $A$. miracollis, having instead a dark background with pale dots on the body or lacking spots.

The río Beni basin, upper rio Madeira, is included within the Mamore-Madre de Dios Piedmont Ecoregion with 21-29\% endemic species of freshwater fish (Abell et al., 2008). However, few recent studies have been published contributing to the limited taxonomic understanding of the ichthyofauna from that region. Ancistrus marcapatae shares the presence of a keel formed by preadipose plates with $A$. bufonius (Valenciennes, 1840), A. greeni (Isbrücker, 2001), A. montanus, A. tolima Taphorn, Armbruster, Villa-Navarro, Ray, 2013 and $A$. vericaucanus; and teeth with sharp elongated principal cusp, at least three times larger than lateral cusp with A. bufonius and A. montanus. Ancistrus marcapatae can be diagnosed by the orbital diameter (14.0$16.7 \%$ in HL vs. $12.3-14.1 \%$ in $A$. bufonius); tooth shape (bicusp vs. unicusp in A. greeni); and dentary width (24.9$29.5 \%$ in HL vs. $18.0-21.3 \%$ in $A$. montanus, $14.2-23.4 \%$ in A. tolima and $12.7-14.8 \%$ in A. vericaucanus, data on the last two species from Taphorn et al., 2013).

Despite major contributions to the knowledge of the ichthyofauna of the rio Madeira basin lately (Queiroz et al., 2013), the species composition of this basin is still poorly known. The apparent endemic presence of some loricariids suggests that the family is highly successful and diverse in the region.

Comparative material examined. Material examined in addition to that listed by Bifi et al. (2009) and de Oliveira et al. (2015, 2016). Ancistrus claro. MCP 28667 (ex ZMB 32918), $67.8 \mathrm{~mm}$ SL, holotype of $A$. claro Knaack, 1999, Brazil, Mato Grosso, rio
Cuiabá basin. Ancistrus cryptophthalmus. MCP 10523, 1, 49.2 mm SL, paratype of A. cryptophthalmus Reis, 1987, Brazil. Ancistrus cuiabae. MCP 28671 (ex ZBM 32920), 112.8 mm SL, holotype of A. cuiabae Knaack, 1999, Brazil, Mato Grosso, rio Cuiabá basin. Ancistrus galani. MCP 15634, 1, 55.9 mm SL, paratype of A. galani Peres, Vilória, 1994, Venezuela, Zulia, río Socuy. Ancistrus greeni. BMNH 1903.10.12.3-4, 2, 44.8-51.4 mm SL, syntype of C. maculatus Regan, 1904, replaced by C. greeni Isbrücker, 2001, Peru, Rozmaiu. Ancistrus malacops. INPA 2393, 2, 55.0-69.1 mm SL, Brazil Amazonas, rio Japurá; INPA 49272, 7, 29.3-110.8 mm SL, Brazil Amazonas, rio Japurá. Ancistrus megalostomus. CAS 64614, 2, 81.7-83.5 mm SL syntypes of $A$. megalostomus Pearson, 1924, Huachi, Bolivia, río Beni basin; MUSM 10366, 1, $64.9 \mathrm{~mm}$ SL, Peru, Sandia, rio Candamo; MUSM 11606, 2, 70.5-85.5 mm SL, Peru, rio Ebehuabaeji basin. Ancistrus montanus. BMNH 1902.12.18.4, $81.3 \mathrm{~mm}$ SL, holotype of X. montana Regan, 1904, Bolivia, Tumupasa, río Beni basin; MUSM 57817, 1, $82.0 \mathrm{~mm}$ SL, Peru, Paucartambo, rio Blanco; MUSM 57830, 1, 48.5 mm SL, Peru, rio Huacaria.

\section{Acknowledgments}

The Secretaria de Desenvolvimento Sustentável do Amazonas (SDS) and the Instituto Nacional de Pesquisas da Amazônia (INPA) provided logistical and technical support for the Sucunduri Expedition to the Mosaic of Apuí, Amazonas State. We are grateful to Roberto E. Reis and an anonymous reviewer for the comments and to Adrian Barnett for reviewing the English. AGB is grateful to Anja Palandacic and Ernst Mikschi (NMW), Carlos Lucena and Margarete Lucena (MCP), Guy Duhamel and Aurelie Laurent (MNHN), James Maclaine and Oliver Crimmen (BMNH), Hernán Ortega (MUSM), and Mark Sabaj and Mariangeles Arce (ANSP) for hospitality during museum visits. We also thank John Lundberg (ANSP), Vinícius Abilhoa (MHNCI), Paulo Buckup (MNRJ) and Osvaldo Oyakawa (MZUSP) for loaning of material. Financial support: AGB benefited from a DCR/AM fellowship from Fundação de Amparo à Pesquisa do Estado do Amazonas - FAPEAM and Conselho Nacional de Desenvolvimento Científico e Tecnológico - CNPq (process 062.01066/2015) and grants to analyze the type material in $\mathrm{BMNH}, \mathrm{MNHN}$, MUSM and NMW. Visit to The Academy of Natural Sciences of Philadelphia (ANSP) supported in part by Böhlke Award to AGB.

\section{References}

Abell R, Thieme ML, Revenga C, Bryer M, Kottelat M, Bogutskaya N, Coad B, Mandrak N, Balderas SC, Bussing W, Stiassny MLJ, Skelton P, Allen GR, Unmack P, Naseka A, Ng R, Sindorf N, Robertson J, Armijo E, Higgins JV, Heibel TJ, Wikramanayake E, Olson D, López HL, Reis RE, Lundberg JG, Sabaj Pérez MH, Petry P. Freshwater ecoregions of the world: a new map of biogeographic units for freshwater biodiversity conservation. BioScience. 2008; 58(5):403-14. 
Armbruster JW. Phylogenetic relationships of the suckermouth armoured catfishes (Loricariidae) with emphasis on the Hypostominae and the Ancistrinae. Zool J Linn Soc. 2004; 141(1):1-80.

Armbruster JW. The genus Peckoltia with the description of two new species and a reanalysis of the phylogeny of the genera of the Hypostominae (Siluriformes: Loricariidae). Zootaxa. 2008; 1822:1-76.

Bifi AG, Pavanelli CS, Zawadzki CH. Three new species of Ancistrus Kner, 1854 (Siluriformes: Loricariidae) from the rio Iguaçu basin, Paraná State, Brazil. Zootaxa. 2009; 2275:41-59.

Ferraris CJ, Jr. Checklist of catfishes, recent and fossil (Osteichthyes: Siluriformes), and catalogue of siluriform primary types. Zootaxa. 2007; 1418:1-628.

Fisch-Muller S. Subfamily Ancistrinae (Armored catfishes). In: Reis RE, Kullander SO, Ferraris CJ, Jr., organizers. Check list of the freshwater fishes of South and Central America. Porto Alegre: Edipucrs; 2003. p.373-400.

Fisch-Muller S, Mazzoni R, Weber C. Genetic and morphological evidences for two new sibling species of Ancistrus (Siluriformes: Loricariidae) in upper rio Tocantins drainage, Brazil. Ichthyol Explor Freshw. 2001; 12(4):289-304.

Fricke R, Eschmeyer WN, van der Laan R, editors. Eschmeyer's catalog of fishes: genera, species, references [Internet]. San Francisco: California Academy of Science; 2019 [updated 2019 Feb 4; cited 2019 Mar 2]. Available from: http:// researcharchive.calacademy.org/research/ichthyology/ catalog/fishcatmain.asp

International Union for Conservation of Nature (IUCN). Standards and Petitions Subcommittee. Guidelines for using the IUCN Red List Categories and Criteria. Version 13 [Internet]. 2017 [accessed 2018 July]. Available from: http://www.iucnredlist. org/documents/RedListGuidelines.pdf

Isbrücker IJH. Classification and catalogue of the mailed Loricariidae (Pisces, Siluriformes). Amsterdam: Instituut voor Taxonomische Zoöogie, Universiteit van Amsterdam; 1980. (Verslagen en Technische Gegevens; No 22).

Lujan NK, Armbruster JW, Lovejoy NR, Lopez-Fernandez H. Multilocus molecular phylogeny of the suckermouth armored catfishes (Siluriformes: Loridariidae) with a focus on subfamily Hypostominae. Mol Phylogenet Evol. 2015b; 82(Pt A):269-88.

Lujan NK, Meza-Vargas V, Astudillo-Clavijo V, Barriga-Salazar R, López-Fernandez H. A multilocus molecular phylogeny for Chaetostoma clade and species with a review of Chaetostoma (Siluriformes: Loridariidae) from the Central Andes. Copeia. 2015a; 103(3):664-701.

de Oliveira RR, Rapp Py-Daniel LH, Zawadzki CH, Zuanon J. Two new Amazonian species of Ancistrus with vestigial adipose fin, with an appraisal on adipose fin loss in neotropical armoured catfishes (Teleostei: Loricariidae). Ichthyol Explor Freshw. 2016; 27(1):67-80. de Oliveira RR, Zuanon J, Zawadzki CH, Rapp Py-Daniel LH. Ancistrus maximus, a new species of red-dotted armored catfish from rio Branco, Roraima State, Brazilian Amazon (Siluriformes: Loricariidae). Ichthyol Explor Freshw. 2015; 26(1):73-82.

Ortega H, Vari RP. Annotated checklist of the freshwater fishes of Peru. Washington, (DC): Smithsonian Institution Press; 1986. (Smithsonian Contributions to Zoology, no. 437).

Oyakawa OT, Akama A, Zanata AM. Review of the genus Hypostomus Lacépède, 1803 from rio Ribeira de Iguape basin, with description of a new species (Pisces, Siluriformes, Loricariidae). Zootaxa. 2005; 921(1):1-27.

Pearson NE. The fishes of the eastern slope of the Andes. I. The fishes of the rio Beni basin, Bolivia, collected by the Mulford expedition. Indiana Univ Sci Ser. 1924; 11(64):1-83.

Queiroz LJ, Torrente-Vilara G, Ohara WM, Pires THS, Zuanon J, Doria CRC, organizers. Peixes do Rio Madeira. Obra em 3 vol. São Paulo: Dialeto Latin American Documentary; 2013.

Regan CT. A monograph of the fishes of the family Loricariidae. Trans Zool Soc London. 1904; 17(Pt 3):191-350.

Regan CT. Descriptions of new fishes of the family Loricariidae in the British Museum Collection. Proc Zool Soc London. 1912; (Pt 3, art 36):666-70.

Schaefer SA. The Neotropical cascudinhos: systematics and biogeography of the Otocinclus catfishes (Siluriformes: Loricariidae). Proc Acad Nat Sci Philadelphia. 1997; 148:1-120.

Secretaria de Desenvolvimento Sustentável do Amazonas (SDS). Plano de gestão do mosaico de Unidades de Conservação do Apuí. Apuí: WWF; CEUC/Amazonas; SDS; Governo do Estado do Amazonas; 2010. (Série Técnica Planos de Gestão; vol. 1 e 2).

Steindachner F. Beiträge zur Kenntniss der Flußfische Südamerikas: V. Anz Kais Akad Wiss Wien, Math-Naturwiss K1. 1915; 93:15-106.

Taylor WR, Van Dyke GC. Revised procedures for staining and clearing small fishes and other vertebrates for bone and cartilage study. Cybium. 1985; 9(2):107-19.

Taphorn DC, Armbruster JW, Villa-Navarro F, Ray CK. TransAndean Ancistrus (Silurifomes, Loricariidae). Zootaxa. 2013; 3641:343-70.

Weber C. Subfamily Hypostominae (Armored catfishes). In: Reis RE, Kullander SO, Ferraris CJ, Jr., organizers. Check List of the Freshwater Fishes of South and Central America. Porto Alegre: Edipucrs; 2003. p.351-372.

Zawadzki CH, Chamon CC. Hypostominae. In: Queiroz LJ, Torrente-Vilara G, Ohara WM, Pires THS, Zuanon J, Doria CRC, organizers. Peixes do rio Madeira. São Paulo: Dialeto Latin American Documentary; 2013. vol. 2; p.302-337.

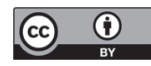

Submitted October 15, 2018 Accepted May 12, 2019 by Marcelo Britto 
